\title{
Tingkat Stres Siswa Saat Pembelajaran Olahraga Secara Daring Di Masa Pandemi
}

\section{Stress Level Of Students During Online Sports Learning During Pandemic}

\author{
Elzas Nurajab ${ }^{1}$, Sony Hasmarita ${ }^{2}$, Bangbang Syamsudar ${ }^{3}$, Vicki \\ Ahmad Karisman ${ }^{4}$ \\ 1,2,3,4 Program studiPJKR, STKIP Pasundan, Jalan Permana No. 32B Kota Cimahi, Jawa Barat, \\ 40553, Indonesia
}

\begin{abstract}
Abstrak
Tujuan Penelitian ini adalah untuk mengetahui seberapa besar Tingkat Stres Siswa Saat Melaksanakan Pembelajaran Olahraga Secara Dairng di masa pandemic ini jika dilihat berdasarkan setiap indikator dari kedua faktor yaitu intrinsik dan ekstrinsik. Dari hasil penelitian yang didapat, peneliti mengambil 100 responden baik tingkat SD, SMP, dan SMA menggunakan kuesioner dengan jumlah item soal sebanyak 32 item soal untuk SD, 20 item soal untuk SMP dan 33 item soal untuk SMA yang sudah diuji validitas dan reliabilitas. Teknik pengumpulan data yang dilakukan disini penelitian dilakukan secara online menggunakan bantuan media sosial seperti Whatsapp dan Google form. Setelah data terkumpul kemudian data dianalisis menggunakan rumus persentase dengan hasil penelitian seluruh indikatornya jika ditotal hasilnya untuk jenjang SD mendapat 55\%, SMP mendapat 58,612\%, dan SMA 61,524 \% maka tingkat stress saat pembelajaran olahraga secara daring paling tinggi yaitu pada jenjang SMA sederajat sebesar 61,524\%. Jika dilihat dari interval kelas maka baik jenjang SD, SMP, dan SMA tingkat stres saat belajar olahraga daring seluruhnya masuk dalam kategori interval sedang.
\end{abstract}

Kata kunci: Tingkat Stres, Olahraga,Pandemi

\begin{abstract}
The purpose of this study is to find out how much stress students when carrying out sports learning in this pandemic period when viewed based on each indicator of both factors, namely intrinsic and extrinsic. From the results of the study obtained, researchers took 100 respondents both elementary, junior high, and high school levels using questionnaires with the number of problem items as many as 32 problem items for elementary school, 20 problem items for junior high school and 33 problem items for SMA that have been tested for validity and reliability. Data collection techniques conducted here research is done online using the help of social media such as Whatsapp and Google form. After the data is collected then the data is analyzed using the percentage formula with the results of research all indicators if the results for elementary level get 55\%, junior high school gets 58.612\%, and SMA $61.524 \%$ then the level of stress when learning sports online is highest, namely at the equivalent high school level of 61,524\%. When viewed from the class intervals, both elementary, junior high, and high school levels of stress when learning sports online all fall into the category of moderate intervals.
\end{abstract}

Keywords: Stress levels, sports, pandemi

Correspondence author: Elzas Nurajab/Sony Hasmarita/Bangbang Syamsudar/Vicki Ahmad Karisman /, STKIP Pasundan Cimahi, Indonesia.

Email: mazisram@gmail.com./ bangbangsyamsudar87@gmail.com/Sony 


\section{Pendahuluan}

Di masa pandemi covid-19 ini khususnya, seluruh aktifitas masyarakat di seluruh negara terjangkit dibatasi karena bisa menyebabkan penularan lebih parah apabila masyarakat melakukan aktifitas diluar ruangan secara bebas dan beramai ramai, sesuai himbauan dari pemerintah kegiatan seluruhnya dialihkan ke aktifitas di rumah demi menjaga setiap masyarakat dari penularan virus ini. Dengan adanya virus covid-19 pemerintah membuat beberapa kebijakan untuk menghentikan penyebaran wabah ini, seperti melakukan lockdown di daerah yang sudah termasuk ke dalam zona merah penyebaran virus, lalu physical quarantine untuk menghindari penyebaran virus secara kontak fisik. Tentunya dengan adanya kebijakan ini masyarakat dunia mulai merasakan dampak yang terjadi di sektor ekonomi dan kondisi psikis masyarakat yang mulai terpengaruh dengan adanya wabah ini (Nurkholis, 2020).

Mulai dari pekerjaan, wisata, bahkan dunia pendidikan pun dialihkan menjadi aktifitas dirumah, berbicara soal pendidikan, pembelajaran diubah menjadi model dalam jaringan dimana peserta didik tidak diperbolehkan untuk melaksanakan kegiatan belajar mengajar di sekolah karena rentan nya penularan dan masih belum ditemukannya vaksin penawar virus ini. Surat edaran Kementrian Pendidikan dan Kebudayaan (Kemendikbud) Direktorat Pendidikan Tinggi No 1 tahun 2020 tentang pencegahan penyebaran Corona Virus Disease (Covid-19) di perguruan tinggi. Melalui surat edaran itu Kemdikbud memberikan instruksi kepada seluruh jenjang pendidikan untuk menyelenggarakan PJJ (Pembelajaran Jarak Jauh) dan para peserta didik pun harus mengkarantina diri dirumah sehingga pembelajaran dilaksanakan full online tidak tatap muka. Di dalam surat tersebut dimuat 10 poin yang salah satunya berupa himbauan untuk mengubah pembelajaran tatap muka menjadi pembelajaran jarak jauh (Firman \& Rahayu, 2020).

Aktivitas pendidikan selama pandemi ini meliputi Pembelajaran Jarak Jauh menggunakan media gadget, internet, video conference, live streaming 2 arah. Wabah COVID-19 mendesak pengujian pendidikan jarak jauh hampir yang belum pernah dilakukan secara serempak sebelumnya (Herliandry, Nurhasanah, Suban, \& Heru, 2020) Kondisi pandemi saat ini mendesak untuk melakukan inovasi dan adaptasi terkait pemanfaatan teknologi yang tersedia untuk mendukung proses pembelajaran tanpa adanya tatap muka dengan pendidik maupun peserta didik (Wahyono, Husamah, \& Budi, 2020).

Adapun dampak yang dirasakan murid pada proses belajar mengajar di rumah adalah para murid merasa dipaksa belajar jarak jauh tanpa sarana dan prasarana memadai di rumah. Proses pembelajaran tidak selalu berjalan dengan lancar dalam pelaksanaannya 
apalagi di daerah terpencil yang sangat terbatas dalam hal fasilitas pembelajaran jarak jauh (Cahyati \& Kusumah, 2020). Padahal fasilitas sarana dan prasarana belajar ini sangat penting guna menunjang pembelajaran jarak jauh selama pandemi ini. Kemudian dampak selanjutnya yaitu murid belum terbiasa dengan budaya belajar jarak jauh karena selama ini murid terbiasa melaksanakan pembelajaran secara tatap muka, terbiasa berinteraksi dengan guru dan teman temannya. Lalu para siswa pun memerlukan waktu lebih untuk menyerap ilmu yang diajarkan saat 3 pembelajaran jarak jauh dan cenderung lebih stress dan jenuh karena kegiatan pembelajaran cenderung monoton. Selama siswa belajar di rumah menumbuhkan perasaan bosan yang dialami oleh siswa yang berakibat mereka mengalami stress karena anak-anak memiliki sifat yang bereksplorasi dengan lingkungan (Tabi'in, 2020). Dampak terhadap orangtua yaitu pengeluaran lebih besar karena harus membeli paket internet untuk menunjang anaknya belajar selama pandemi, kemudian menambah beban orangtua karena PJJ ini mengharuskan orangtua turut andil untuk mendampingi anaknya dalam belajar, seperti membaca, menulis, dan sebagainya. Selain itu, tingkat pendidikan orang tua terutama ibu terdapat perbedaan pada tingkat stress pada saat mendampingi anak-anaknya ditingkat sekolah dasar selama belajar dirumah dimasa pandemic covid-19 (Palupi, 2021). Tidak semua orang tua bisa menunjang kebutuhan anaknya karena ada yang pekerjaannya terdampak covid19 sehingga finansial keluarga terhambat, ada yang orangtuanya tidak bisa mendampingi anaknya karena bekerja, ataupun ada juga orangtua yang tidak memiliki fasilitas gadget sebagai sarana untuk melaksanakan pembelajaran. Dampak yang dirasakan guru pun tidak kalah beratnya, karena tidak semua guru mahir dalam menggunakan fasilitas pembelajaran online dan perlu bimbingan serta pelatihan terlebih dahulu.

Kemudian tidak semua sekolah memfasilitasi gurunya dengan baik karena kendala biaya dan sebagainya, karena seharusnya untuk belajar online ini guru disediakan fasilitas sarana prasarana yang memadai agar pembelajaran berjalan dengan baik. Kemudian para guru pun perlu adaptasi dengan system belajar jarak jauh dimana yang biasanya berinteraksi dengan siswanya, diharuskan untuk memaksimalkan penyampaian pembelajaran lewat media online (jarak jauh). Kemudian guru pun akan stress, jenuh, dan kehilangan jiwa social karena adanya tuntutan untuk menyelenggarakan pembelajaran yang biasanya guru berinteraksi dengan murid, orangtua murid, dan guru lainnya dipaksa untuk melaksanakan pembelajara secara jarak jauh (Wahyono et al., 2020).

Berdasarkan data yang diperoleh Perhimpunan Dokter Spesialis Kedokteran Jiwa Indonesia (PDSKJI) yang meneliti tentang perkembangan psikologis masyarakat saat pandemi COVID-19 menunjukkan bahwa 64,3\% dari 1.522 responden mengalami 
masalah kecemasan/stress sebagai dampak dari adanya pandemi ini. Responden tersebut terdiri dari perempuan sebanyak 76,1\% yang berusia dari 14 tahun-71 tahun. Mereka berasal dari beberapa wilayah yaitu Jawa Barat (23,4 \%), Jawa Tengah (15,5 \%), Jawa Timur $(12,8 \%)$, dan DKI Jakarta (16,9\%). Salah satu faktor penyebab tingkat stress anak remaja saat ini adalah karena mereka mengalami kesulitan saat harus belajar di rumah akibat pandemi. Mereka beranggapan bahwa dengan sistem daring ini, pembelajaran menjadi kurang efektif untuk dilaksanakan. Dari survei yang dilakukan KPAI, sebanyak $79,9 \%$ anak berpendapat bahwa interaksi berkurang dan guru hanya memberikan tugas berat saja sehingga anak mengalami peningkatan stress dan 20,1\% yang menganggap adanya interaksi dalam proses pembelajaran. Ternyata, dampak negatif dari adanya peraturan seperti Social \& Physical Distancing serta PSBB, anak-anak merasa jiwanya menjadi lebih tertekan (D, Ananda, \& Apsari, 2020).

Stres merupakan keadaan dimana seseorang yang mengalami ketegangan karena adanya kondisi-kondisi yang mempengaruhi dirinya. Dalam bukunya Psikologi Klinis Ardani stres adalah tekanan internal maupun eksternal serta kondisi bermasalah lainnya dalam kehidupan (an internal and eksternal pressure and other troublesome condition life). Lazarus dalam Hasan mengembangkan teori penilaian kognitif (cognitive appraisal) untuk memberikan penjelasan tentang stres dalam lingkup yang luas. Ia memberikan definisi stres yang mencakup berbagai faktor, yang terdiri dari stimulus, tanggapan, penilaian kognitif terhadap ancaman, gaya pertahanan (coping styles), perlindungan psikologis dan situasi sosial. Lazarus menilai bahwa ancaman (threat) merupakan kata kunci dari stres, yang dinilai secara subjektif ketika seseorang mempersepsikan efek negatif potensial dan stressor (Hasan, 2013) .

Kata stress berasal dari kosakata Bahasa Inggris. Menurut Kamus Oxford, stress memiliki paling tidak enam pengertian, sesuai penggunaannya dibidang-bidang yang berbeda. Disana stress diterjemahkan sebagai: (1) tekanan atau kecemasan yang disebabkan oleh masalah-masalah dalam kehidupan seseorang; (2) tekanan yang diberikan ke suatu benda yang bisa merusak benda ituatau menghilangkan bentuknya; (3) kepentingan khusus yang diarahkan kepadasesuatu; (4) suatu kekuatan ekstra yang dikerahkan ketika mengucapkan suatukata khusus; (5) suatu kekuatan ekstra yang digunakan untuk membuat suarakhusus dalam musik; (6) penyakit yang ditimbulkan oleh kondisi fisik yangterganggu. Stres merupakan bagian dari kehidupan manusia sehari-hari (Zannah, 2013). Stres bersifat individu dan pada dasarnya bersifat merusak bila tidak adanya keseimbangan antara daya tahan mental individu dengan beban stres yang dirasakan (Wulandari, 2014). 
Penelitian sebelumnya yang membahas mengenai tingkat stress siswa dalam belajar dimasa pandemi ini telah banyak menghasilkan teori yang mengemukakan tingkat stres siswa.Tingkat stress anak dalam belajar dimasa pandemi di daerah terpencil kabupaten Hulu Sungai Utara sangat tinggi (Husin \& Sawitri, 2021). Selanjutnya penelitian lain mengemukakan bahwa masish banyak dari peserta didik yang mengalami kecemasan, stress, dan depresi akibat proses pembelajaran jarak jauh (Lindasari, Nuryani, \& Sukaesih, 2021). Hasil penelitian di atas menunjukan bahwa dimasa pandemi ini tingkat stress anak sangat tinggi, namun penelitian tersebut terkhusus pada bidang psikologis dan faktor daerah.

Berdasarkan latar belakang dan penelitian terdahulu yang sudah dipaparkan sebelumnya, maka penelitian di dalam bidang lain dirasa sangat penting untuk dilakukan. Penulis tertarik untuk melakukan penelitian yang perlu dilakukan berkaitan dengan tingkat stress guru dan siswa dalam menghadapi pembelajaran penjas secara online (daring). Oleh karena itu penulis akan melaksanakan penelitian dengan judul "Tingkat Stres Siswa Saat Pembelajaran Olahraga Secara Daring Di Masa Pandemi”.

\section{METODE}

Metode adalah suatu cara atau jalan yang ditempuh untuk mencapai sesuatu tujuan. Tujuan penelitian ini adalah untuk mengungkapkan, menggambarkan dan menyimpulkan data guna memecahkan suatu masalah melalui cara-cara tertentu yang sesuai dengan prosedur penelitian. Metode merupakan cara yang ditempuh dalam melakukan sebuah penelitian (Sudharma, 2014). Ketepatan dalam menggunakan sebuah metode akan memberikan hasil yang optimal terhadap hasil dari penelitian. Metode penelitian digunakan sebagai upaya untuk memperoleh data, dengan tujuan memperoleh jawaban dari permasalahan penelitian, Metode penelitian pada dasarnya merupakan cara ilmiah untuk mendapatkan data dengan tujuan dan kegunaan tertentu (Widarto, 2013).

Metode penelitian yang digunakan penulis dalam penelitian ini dengan melihat pertimbangan yang ada adalah dengan metode penelitian Ex Post Facto. Sukardi (2003) menjelaskan mengenai Ex Post Facto bahwa “ penelitian Ex post Facto merupakan penelitian di mana rangkaian variabel-variabel bebas telah terjadi, ketika peneliti mulai melakukan pengamatan terhadap variabel terikat". Ciri utama dalam penelitian ex post facto dapat dijelaskan oleh Natsir (1999) sebagai berikut "sifat penelitian ex post facto yaitu tidak ada kontrol terhadap variabel.Variabel dilihat sebagaimana adanya". pada penelitian ini, peneliti tidak memulai prosesnya dari awal, tetapi langsung mengambil hasil (Widarto, 2013). Studi korelasi menurut Sudjana dan Ibrahim, adalah penelitian 
yang mempelajari hubungan dua variabel atau lebih, yakni sejauh mana variasi dalam satu variabel berhubungan dengan variasi dalam variabel lain. Sedangkan menurut Arikunto "penelitian korelasi bertujuan untuk menemukan ada tidaknya hubungan dan apabila ada, berapa eratnya hubungan serta berarti atau tidak hubungan itu (Anggraini \& Oliver, 2019)

Populasi dalam penelitian ini adalah Siswa di Sekolah yang berada dalam Zona C khususnya Kecamatan Kiaracondong dan Regol, dan Zona D khususnya Kecamatan Astanaanyar yang berjumlah $\backslash 100$ Siswa jenjang SD,100 Siswa jenjang SMP 100 Siswa jenjang SMA yang berada dalam Zona B, Zona C dan Zona D Kota Bandung.

Dari hasil perhitungan berdasarkan rumus Slovin diatas maka minimal pengambilan sampel adalah sebesar 80 orang. Maka dari itu sampel yang dipilih dalam penelitian ini yaitu 100 Siswa jenjang SD,100 Siswa jenjang SMP 100 Siswa jenjang SMA yang berada dalam Zona B, Zona C dan Zona D Kota Bandung.

Teknik pengumpulan data yang dilakukan disini penelitian dilakukan secara online menggunakan bantuan media sosial seperti Whatsapp dan Google form. Link dibagikan melalui Wali Kelas/Guru Olahraga di sekolah dan dibagikan kepada 100 siswa sebagai responden.

Untuk analisis yang susai dengan pendekatan penelitian tersebut, rumus yang digunakan dalam penelitian ini adalah sebagai berikut: 1. Persentase, 2. Rata-Rata, 3. Simpangan Baku dan Variansi.

\section{HASIL DAN PEMBAHASAN}

\section{Hasil}

Setelah diadakan penelitian dengan menggunakan penyebaran angket/kuesioner melalui Google form dengan item pertanyaan sebanyak 32 untuk jenjang SD, 20 soal untuk jenjang SMP, dan 33 Soal untuk jenjang SMA dan jumlah responden sebanyak 100 orang per jenjang sekolah. Dari setiap indikator pertanyaan akan dibahas nantinya akan diketahui seberapa besar tingkat stress siswa saat menghadapi pembelajaran olahraga yang dilakukan secara daring. Ada 2 faktor yang mempengaruhi tingkat stres siswa tersebut diantaranya adalah faktor intrinsik (faktor dari dalam diri) dan ekstrinsik (faktor dari luar). Faktor intrinsik itu sendiri memiliki 2 indikator yaitu mental psikis dan tubuh. Faktor ekstrinsik sendiri memiliki 3 indikator diantaranya adalah sosial, kepuasan dan tekanan. Dari hasil penelitian dapat diketahui gambaran tentang seberapa besar tingkat stress siswa saat menghadapi pembelajaran olahraga yang dilakukan secara daring pada jenjang SD, SMP dan SMA. Distribusi responden setiap butir soal pada tiap tiap komponen indikator dapat diuraikan sebagai berikut : 


\section{Tabel 1}

Data Persentase Hasil Penelitian Tingkat Stress Siswa Saat Pembelajaran Daring

\begin{tabular}{cccccc}
\hline \multirow{2}{*}{$\begin{array}{c}\text { Jenjang } \\
\text { Sekolah }\end{array}$} & \multicolumn{7}{c}{ Persentase Faktor Penyebab Stres } \\
\hline & \multicolumn{3}{c}{ Intrinsik } & \multicolumn{2}{c}{ Ekstrinsik } \\
\cline { 2 - 6 } & $\begin{array}{c}\text { Mental } \\
\text { Psikis }\end{array}$ & Subuh & Kepial & Tekanan & \\
\hline SD & $\mathbf{5 5 , 7 5 \%}$ & $\mathbf{5 2 , 9 2 5 \%}$ & $\mathbf{5 4 , 8 2 \%}$ & $\mathbf{5 6 , 8 \%}$ & $\mathbf{5 4 , 7 \%}$ \\
\hline SMP & $\mathbf{5 5 , 8 6 \%}$ & $\mathbf{5 6 , 1 \%}$ & $\mathbf{5 3 , 2 \%}$ & $\mathbf{5 6 , 9 \%}$ & $\mathbf{7 1 \%}$ \\
\hline SMA & $\mathbf{6 1 , 8 7}$ & $\mathbf{6 8 , 1 3 \%}$ & $\mathbf{5 3 , 7 7}$ & $\mathbf{6 4 , 6 \%}$ & $\mathbf{5 9 , 2 4 \%}$ \\
& $\%$ & & $\%$ & & \\
\hline
\end{tabular}

\section{Faktor Intrinsik}

Berdasarkan hasil dari analisis data yang diperoleh, pada faktor intrinsik dengan indikator mental psikis dan tubuh ini memiliki hasil persentase sebagaiberikut :

\section{a. Mental psikis}

Analisis data pada factor intrinsic dengan indicator mental psikis memperoleh persentase dengan skor yakni SD : 55,75\%, SMP : 55,86\%, dan SMA 61,875\%. Jika dilihat dan dibandingkan indikator mental psikis ini paling tinggi persentasenya di jenjang SMA.

\section{b. Tubuh}

Kemudian factor intrinsic dengan indicator tubuh memiliki hasil persentase yakni SD : $52,925 \%$, SMP : 56,1\%, SMA : 68,13\%. Dapat disimpulkan apabila dibandingkan antara ketiga jenjang sekolah tersebut factor intrinsic dengan indicator tubuh ini paling tinggi pengaruhnya terhadap tingkat stress siswa saat belajar olahraga daring pada jenjang SMA.

Data diatas diperoleh dari hasil survei online terhadap responden dengan menggunakan google form yang disebarkan lewat guru pendidikan jasmani di sekolah yang bersangkutan di tiap jenjang tersebut. Dengan hasil yang sudah didapat, factor penyebab stres dari dalam faktor intrinsik ini berpengaruh sangat besar dengan adanya faktor dari mental psikis siswa dan kemampuan tubuh siswa.

Dengan hasil analisis data persentase yg diperoleh maka dapat disimpulkan bahwa factor intrinsic penyebab stress tertinggi untuk SD yaitu mental psikis sebesar 55,75\%, SMP yaitu kemampuan tubuh sebesar 56,1\%, dan SMA yaitu kemampuan tubuh dengan hasil persentase tertinggi yaitu $68,13 \%$. 


\section{Faktor Ekstrinsik}

Dari hasil penelitian tentang tingkat stress siswa saat pembelajaran olahraga secara daring ada faktor ekstrinsik memiliki 3 indikator yang berpengaruh bagi tingkat stres siswa yaitu indikator sosial, kepuasan, dan tekanan. Untuk lebih jelasnya akan dijelaskan sebagai berikut:

a. Indikator sosial

Dari data yang didapat, untuk indikator sosial ini memperoleh hasil analisis data dengan skor SD : 54,825\%, SMP : 53,2\%, SMA : 53,775\% . Dari Indikator tersebut sangat berpengaruh bagi masing - masing jenjang untuk melaksanakan keberlangsungan kegiatan belajar mengajar mata pelajaran olahraga secara daring di sekolah yang bersangkutan.

b. Indikator kepuasan

Pada indikator kepuasan yang dimaksud yaitu ketidakpuasan siswa dalam mendapatkan hak dan kewajibannya dalam mendapatkan pelayanan pendidikan yang layak, khususnya selama pandemic ini yang notabene dilaksanakan secara daring. Indikator kepuasan ini memperoleh hasil yakni untuk SD : 56,8\%, SMP : 56,9\%, dan SMA : 64,6\% . dapat disimpulkan bahwa ketidakpuasan siswa dalam memperoleh hak pelayanan pendidikan tersebut tertinggi pada jenjang SMA dengan persentase 64,6\%

c. Indikator tekanan

Berdasarkan hasil analisis data yang diperoleh, maka faktor tekanan dapat diambil sebuah pengertian dan gambaran yang dimaksud yaitu perasaan tertekan siswa saat sedang melaksanakan pembelajaran olahraga secara daring.

Adapun hasil persentase yang diperoleh yaitu untuk SD :54,7\%, SMP : 71\%, dan SMA : 59,24\%. Maka dapat dipetik kesimpulan untuk indicator tekanan ini yang paling berpengaruh yakni pada jenjang SMP sebesar 71\% terhadap kegiatan belajar mengajar olahraga secara daring ini. Dengan hasil tersebut dapat disimpulkan bahwa indikator tekanan ini sangat berpengaruh karena jika siswa tertekan maka dapat menimbulkan rasa cemas, stress, dan tidak focus untuk menyerap materi.

Berdasarkan data yang diperoleh dari kedua faktor yaitu faktor intrinsik dan faktor ekstrinsik, dapat disimpulkan bahwa setiap indikator masing masing memiliki hasil persentase yang beragam. 


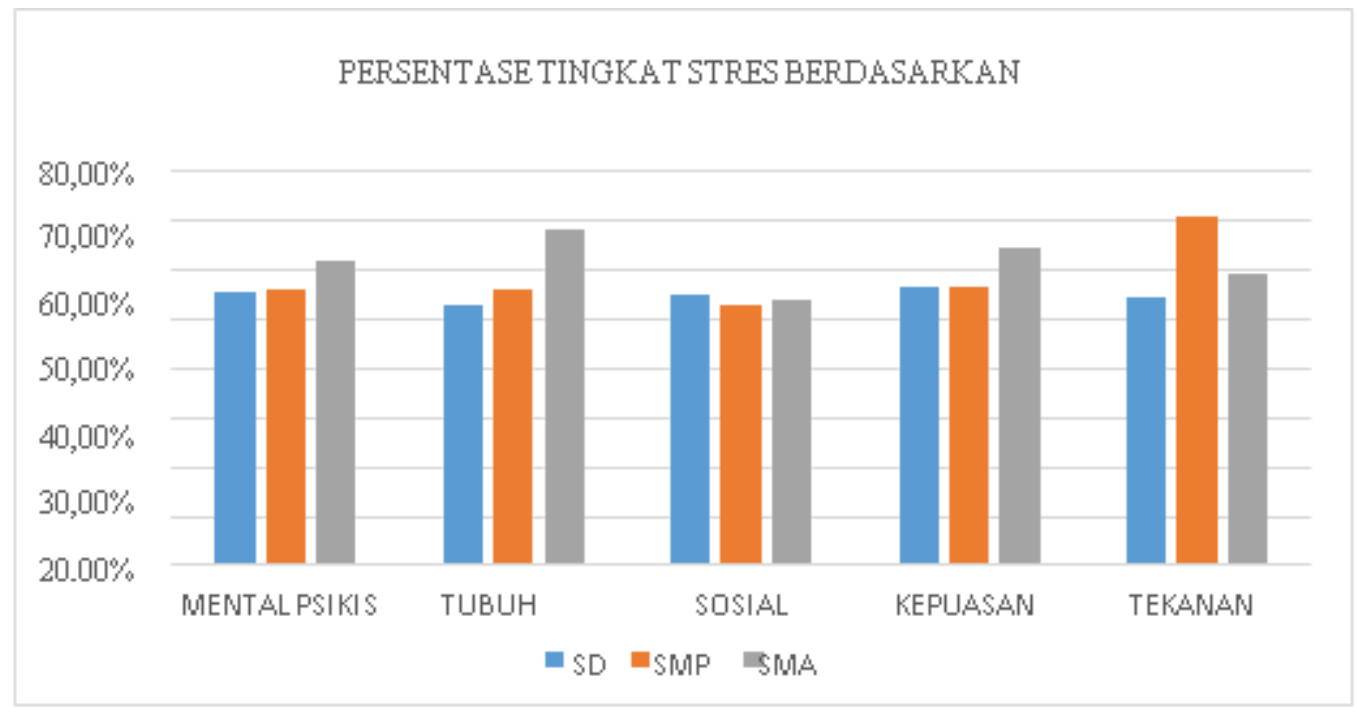

Gambar 1

Diagram Batang Persentase Tingkat Stres siswa saat belajar olahraga daring berdasarkan jenjang dan indikatornya

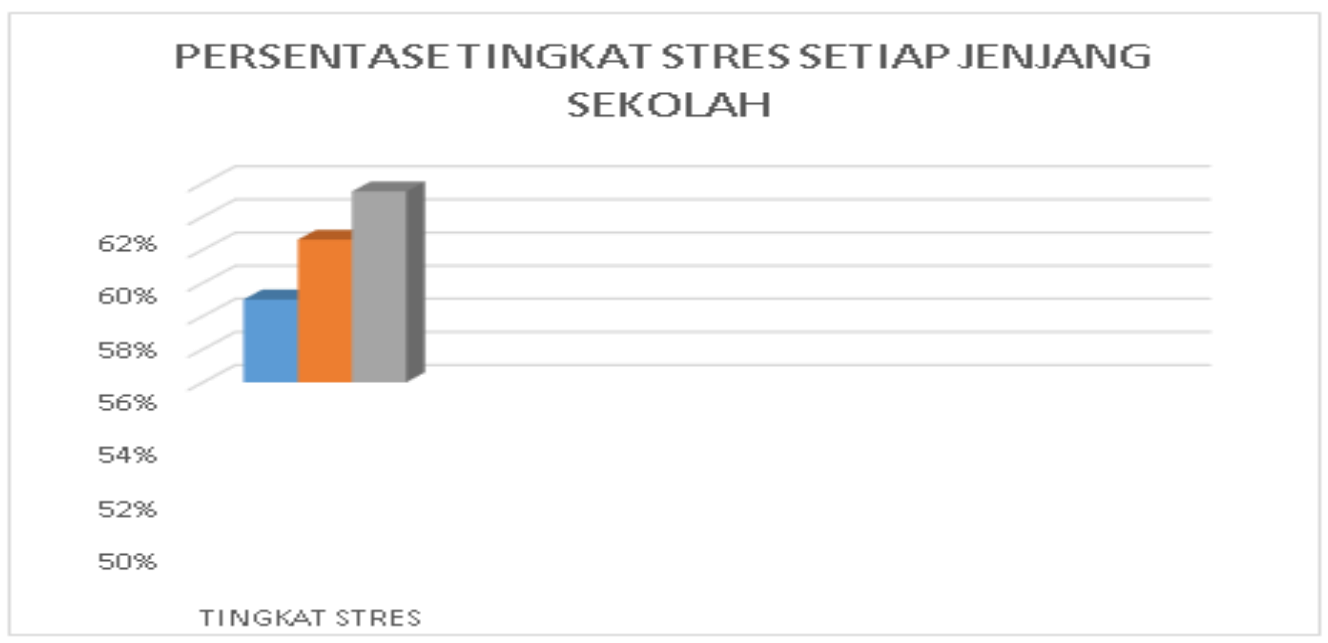

Gambar 2

Diagram batang persentase tingkat stress siswa saat belajar olahraga secara daring per jenjang pendidikan

\section{Pembahasan}

Hasil penelitian mengenai Tingkat Stres Siswa Saat Pembelajaran Olahraga Secara Daring di Masa Pandemi baik itu Sekolah Jenjang SD, SMP dan SMA seluruhnya berada dalam kategori sedang dengan keterangan SD 35\%, SMP 38\% dan SMA 38\%. Hal tersebut menunjukan bahwa, walaupun beberapa siswa mengalami stress pada saat mengikuti pembelajaran olahraga secara daring, namun sebagian besar siswa hanya mengalami tingkat stress yang sedang dalam mengikuti proses belajar olahraga secara daring di rumah. 
Menurut Kamus Oxford, stress memiliki paling tidak enam pengertian, sesuai penggunaannya dibidang-bidang yang berbeda. Disana stress diterjemahkan sebagai: (1) tekanan atau kecemasan yang disebabkan oleh masalah-masalah dalam kehidupan seseorang; (2) tekanan yang diberikan ke suatu benda yang bisa merusak benda ituatau menghilangkan bentuknya; (3) kepentingan khusus yang diarahkan kepadasesuatu; (4) suatu kekuatan ekstra yang dikerahkan ketika mengucapkan suatukata khusus; (5) suatu kekuatan ekstra yang digunakan untuk membuat suarakhusus dalam musik; (6) penyakit yang ditimbulkan oleh kondisi fisik yangterganggu. Stres merupakan bagian dari kehidupan manusia sehari-hari (Zannah, 2013).

Sumber stres atau penyebab stres dikenali sebagai stresor. Stresor adalah segala situasi atau pemicu yang menyebabkan individu merasa tertekan atau terancam. Penyebab stresor dapat di bagi menjadi dua, yaitu stresor eksternal dan stresor internal. Stresor eksternal merupakan stresor berasal dari luar individu seperti stresor yang berada di lingkungan dan stresor sosial yaitu tekanan dari luar disebabkan oleh interaksi individu dengan lingkungannya, banyak stresor sosial yang bersifat traumatic yang tak dapat dihindari, seperti kehilangan orang yang dicintai, kehilangan pekerjaan, pensiun dari pekerjaan, perceraian, masalah keuangan, pindah rumah dan lain-lain. Sedangkan stresor internal merupakan stresor yang berasal dari dari dalam individu seperti stresor psikologis tekanan dari dalam diri individu biasanya yang bersifat negatif seperti frustasi, kecemasan (anxiety), rasa bersalah, kuatir berlebihan, marah, benci, sedih, cemburu, rasa kasihan pada diri sendiri, serta rasa rendah diri. Stresor biologis seperti pelepasan neurotrasmitters saat stres dari kelenjar adrenal, medula yaitu epinefrin dan norepinefrin dalam respon terhadap stres. Pelepasan neurotransmitter menyebabkan efek fisiologis seperti denyut jantung meningkat, peningkatan kewaspadaan dan lain-lain (Wulandari, 2014).

Klasifikasi stres dibagi menjadi tiga tingkatan yaitu stres ringan, sedang dan berat.

1) Stres ringan

Pada tingkat stres ringan adalah stres yang tidak merusak aspek fisiologis dari seseorang. Stres ringan umumnya dirasakan oleh setiap orang misalnya lupa, ketiduran, dikritik, dan kemacetan. Stres ringan sering terjadi pada kehidupan seharihari dan kondisi dapat membantu individu menjadi waspada. Situasi ini tidak akan menimbulkan penyakit kecuali jika dihadapi terus menerus.

2) Stres sedang

Stres sedang terjadi lebih lama, dari beberapa jam hingga beberapa hari. Respon dari tingkat stres ini didapat gangguan pada lambung dan usus misalnya maag, buang air 
besar tidak teratur, ketegangan pada otot, gangguan pola tidur, perubahan siklus menstruasi, daya konsentrasi dan daya ingat menurun. Contoh dari stresor yang menimbulkan stres sedang adalah kesepakatan yang belum selesai, beban kerja yang berlebihan, mengharapkan pekerjaan baru, dan anggota keluarga yang pergi dalam waktu yang lama.

3) Stres berat

Stres berat adalah stres kronis yang terjadi beberapa minggu sampai beberapa tahun. Respon dari tingkat stres ini didapat gangguan pencernaan berat, debar jantung semakin meningkat, sesak napas, tremor, persaan cemas dan takut meningkat, mudah bingung dan panik. Contoh dari stresor yang dapat menimbulkan stres berat adalah hubungan suami istri yang tidak harmonis, kesulitan finansial, dan penyakit fisik yang lama.

Dari uraian di atas dapat disimpulkan bahwa tingkatan stress ada 3,yaitu : stres ringan, stres sedang, dan stres berat. Masing - masing tingkatan stress memiliki dampak tanda dan gejala fisiologis serta psikologis yang berbeda.

\section{KESIMPULAN}

Berdasarkan hasil dari penelitian dan pembahasan mengenai "Tingkat Stres siswa saat pembelajaran olahraga secara daring di masa pandemi” berdasarkan 2 faktor yang ada yaitu faktor intrinsik dan faktor ekstrinsik dapat disimpulkan untuk jenjang SD setelah dijumlahkan persentase seluruh indikatornya mendapat 55\%, SMP mendapat $58,612 \%$, dan SMA 61,524 \% maka tingkat stress saat pembelajaran olahraga secara daring paling tinggi yaitu pada jenjang SMA sederajat sebesar 61,524\%.

\section{DAFTAR PUSTAKA}

Anggraini, A. R., \& Oliver, J. (2019). Pembelajaran. Journal of Chemical Information and Modeling, 53(9), 1689-1699. https://doi.org/10.1017/CBO9781107415324.004

Cahyati, N., \& Kusumah, R. (2020). "Peran Orang Tua Dalam Menerapkan Pembelajaran Di Rumah Saat Pandemi Covid 19,." Jurnal Golden Age, Universitas Hamzanwadi, 4(1), 155.

D, S. S., Ananda, \& Apsari, N. C. (2020). "MENGATASI STRESS PADA REMAJA SAAT PANDEMI COVID-19," 1(1), 67-89.

Firman, F., \& Rahayu, S. (2020). "Pembelajaran Online di Tengah Pandemi Covid-19,." Indones. J. Educ. Sci, 02(02), 81-89. https://doi.org/doi: 10.31605/ijes.v2i2.659.

Hasan. (2013). “Tingakat Keparahan Stres,.” “Tingakat Keparahan Stres, ” 1(2), 12-38.

Herliandry, L. D., Nurhasanah, Suban, M. E., \& Heru, K. (2020). "Pandemic learning during the Covid-19". J. Teknol. Pendidik, 22(1), 65-70. https://doi.org/doi: 
https://doi.org/10. 21009/jtp.v22i1.15286.

Husin, H., \& Sawitri, S. (2021). Covid-19: Tingkat Stres Belajar Anak-Anak Di Daerah Terpencil. Al-Madrasah: Jurnal Pendidikan Madrasah Ibtidaiyah, 5(2), 101. https://doi.org/10.35931/am.v5i2.542

Lindasari, S. W., Nuryani, R., \& Sukaesih, N. S. (2021). Dampak Pembelajaran Jarak Jauh Terhadap Psikologis Siswa Pada Masa Pandemik Covid 19. Jnc, 4(2), 130137.

Nurkholis. (2020). "Dampak Pandemi Novel-Corona Virus Disiase ( Covid-19 ) Terhadap Psikologi Dan Pendidikan Serta Kebijakan Pemerintah,.” PGSD, 06(1), 39-49. https://doi.org/https://e journal.umc.ac.id/index.php/JPS

Palupi, T. N. (2021). Tingkat Stres Ibu Dalam Mendampingi Siswa-Siswi Sekolah Dasar Selama Belajar Di Rumah Pada Masa Pandemi Covid-19. Jp3Sdm, 10(1), 36-48.

Sudharma, M. (2014). "Keberhasilan Cabang Olahraga Yang Membuat Program Latihan dan Yang Tidak Membuat Program Latihan Terhadap Hasil Tes Kemampuan Fisik Atlet Pelatkab Karawang Menuju PORDA 2014."

Tabi'in, A. (2020). "Problematika Stay At Home Pada Anak Usia Dini Di Tengah Pandemi Covid 19,." Jurnal Golden Age, Universitas Hamzanwadi, 4(1), 193.

Wahyono, H., Husamah, \& Budi, A. S. (2020). "Guru profesional di masa pandemi COVID-19: Review implementasi, tantangan, dan solusi pembelajaran daring,." $J$. Pendidik. Profesi Guru, l(1), 51-65. https://doi.org/doi: 10.22219/JPPG.V1I1.12462.

Widarto. (2013). Penelitian Ex Post Facto.

Wulandari, A. (2014). Karakteristik Pertumbuhan Perkembangan Remaja dan Implikasinya Terhadap Masalah Kesehatan dan Keperawatannya. Urnal Keperawatan Anak, 2, 39-43.

Zannah, M. (2013). "Gangguan stres pasca trauma gagal untuk menikah: Studi fenomenologi terhadap seorang perempuan yang mengalami stres pasca trauma gagal untuk menikah,." Univ. Islam Negeri Maulana Malik Ibrahim, 69-78, 87-97. 